\title{
Social adaptability in ecotones: sea-level rise and climate change adaptation in Flushing and the Isles of Scilly, UK
}

\author{
Jan Petzold \\ Alfred Wegener Institute, Bremen, Germany \\ jan.petzold@awi.de
}

\begin{abstract}
Coastal zones and small islands are among the areas most impacted by global climate change and face great challenges for adaptation. While being considered as particularly vulnerable, many coastal communities, nevertheless, have long traditions of living not only $b y$ but with the sea. If such ecotones-places where ecosystems intersect-have features distinct from purely continental regions, the question is how life with the shore translates into adaptability towards environmental change. Life at the shore shapes emergent social relationships, local traditions, and collective memory. At the same time, issues such as tourism development, demographic change, and national and international administrations influence how environmental challenges in coastal areas are addressed. In this paper, I analyse how place-specific social structures and conflicting influences in ecotones affect adaptability to sea-level rise in coastal areas. This research draws on quantitative and qualitative data from a comparative study of two case studies, a coastal town and an archipelago, in Southwest England.
\end{abstract}

Keywords: aquapelago, climate change adaptation, community resilience, ecotones, islands, sea-level rise, social capital, Southwest England

https://doi.org/10.24043/isj.17

(C) 2018 - Institute of Island Studies, University of Prince Edward Island, Canada.

\section{Introduction}

Referring to the coastal shore, and islands, in particular, Gillis (2014, p. 164) wrote in the Island Studies Journal that "now we are beginning to appreciate the centrality of the marginal" both in natural sciences and humanities. Thus, Gillis $(2012,2014)$ suggests applying the concept of ecotones to social systems. Ecotones describe "places where ecosystems intersect, overlap and exist in creative tension with one another" (Gillis, 2014, p. 155), such as the intertidal zone. In island and coastal communities, the relationship of people to their coastal environment is a significant factor in shaping people's perception and behaviour. How does this overlapping and the tension of ecosystems affect people living in and depending on the resources in coastal zones? Can they contribute to a place-specific resilience in times of environmental change?

Climate change is a significant challenge for coastal regions and small islands (Nurse et al., 2014). Sea-level rise, in particular, already shows impacts of ongoing coastal erosion. Projections suggest a further rise in sea level up to a metre by the end of the 21st century (IPCC, 2013). This would lead to increased flooding and land loss and force societies to adapt. Besides technical adaptation measures, such as seawalls, groynes, and sand nourishment, migration or relocation may also be necessary. In any case, adaptation is a social challenge. Strategies and policies have social implications and rely on public support. In addition to top-down approaches, bottom-up approaches, especially community action, are a valuable asset for increasing community resilience to sea-level rise.

Issues such as levels of trust, social networks, and norms-social capital-are indicators of social cohesion, which can contribute to a society's adaptability to environmental (climate) 
change (Adger, 2003; Pelling, 2011). Social capital may become particularly relevant in small and isolated communities, where institutionalised structures are weak. Moreover, different types of social capital, i.e., so-called bonding, linking, networking social capital, allow access to different kinds of resources (Woolcock, 2001). Therefore, it is important to consider not only a community's endogenous structures, but also its setting and external relationships.

The main research question, in relation to the concept of ecotones, is: How do placespecific social features in coastal zones affect community adaptability to sea-level rise?

Small islands provide useful case studies for an inquiry concerning ecotones. It is, however, unclear whether small islands are, in fact, special cases. Many places which are not located on small islands share similar issues of isolation and scale (Kerr, 2005) and have a strong maritime identity. I present the empirical findings from two case studies, of which one is a small archipelago (the Isles of Scilly) and the other is a small coastal village (Flushing). Both are located in the southwest of the United Kingdom. The comparative study is possible here because both are located in the same cultural region with similar political circumstances, and both are affected by sea-level rise.

Section 2 focusses on the theoretical background framing adaptation and resilience from a complexity perspective, combined with features of social capital and in a context of ecotones. Section 3 gives a brief overview of quantitative and qualitative research methods applied in the two case study sites. On this basis, Section 4 presents the empirical findings related to vulnerability and adaptability of the two case studies and explains similarities and differences. A discussion of the results in Section 5 includes the wider context of coastal zones and small islands in times of climate change, before a conclusion in Section 6.

\section{Resilience, social capital, and ecotones}

In this paper, I combine the approaches of community resilience and social capital with the concept of ecotones. According to Gillis (2012), the intertidal zone and the interaction with both the marine and terrestrial environment have historically been crucial for human development. Islands are a suitable example of ecotones because they are so dominantly shaped by the two ecosystems. However, place-based coastal communities on continents also fall into this category.

Hayward's concept of the 'aquapelago'-in contrast to the term 'archipelago'-stresses the marine aspect of island formations as well as interactions between the marine and terrestrial. An aquapelago is:

a social unit existing in a location in which the aquatic spaces between and around a group of islands are utilised and navigated in a manner that is fundamentally interconnected with and essential to the social group's habitation of land and their senses of identity and belonging (Hayward, 2012, p. 5).

The marine environment is, therefore, an essential part of island (and archipelago) identity (cf. Hau'ofa, 1993). However, Hayward also stresses that aquapelagos are "innately linked to and dependent on finite terrestrial resources and constantly react to and work within the transitional zone between land and sea" (Hayward, 2012, p. 1). This latter aspect, similar to the ecotone concept, might therefore add to the general understanding of place-based coastal societies and their interaction with the environment.

The concept of ecotones especially considers environmental changes such as climate change and associated sea-level rise as non-linear developments. In contrast, natural sciences dealing with such phenomena seem to stress positivist assumptions of predicting future realities of drowned landscapes. From a perspective of complexity theory, environmental changes are dynamic and unpredictable. This assumption does not make the development of scenarios as well as adaptation and mitigation strategies superfluous; it "does not negate their value in informing 
society about possible futures. However, it does suggest that these models may not be preparing us for some possible responses" (Harrison \& Stainforth, 2009, p. 111).

Accordingly, community resilience can be defined as "the existence, development, and engagement of community resources by community members to thrive in an environment characterized by change, uncertainty, unpredictability, and surprise" (Magis, 2010, p. 402). Community resilience is an important issue particularly for place-based communities, i.e., communities depending on a healthy environment for people's livelihoods (Berkes \& Ross, 2013). In such communities, the most important ties and relationships are within the geographical community, rather than distant relationships (cf. Maida, 2007; Berkes \& Ross, 2013, p. 13). Accordingly, they may possess a higher vulnerability to the impacts of environmental changes, because they have fewer alternatives to relocate. At the same time, such a reliance on the well-being of local environmental conditions may lead to a higher incentive for sustainable land management (Walker \& Salt, 2006, p. 108). Therefore, acknowledgement of place-specific and societal features is essential for the understanding of adaptation challenges and options (Lyth et al., 2015).

Weichselgartner and Kelman (2015, p. 263) criticize that "too many resilience-building activities draw upon unchallenged assumptions about the social world, effectively imposing a technical-reductionist framework upon more complex webs of knowledge, values and meaningand thus action." In fact, the elements that strengthen community resilience involve people's agency and capacity for self-organisation, e.g., values and beliefs, knowledge, skills, learning, leadership, people-place relationships, economic diversity, community infrastructure, efficient governance system, and social networks (Berkes \& Ross, 2013, p. 14). In the context of climate change and sea-level rise, aspects such as the effective management of coastal resources, risk management, emergency response capacity, and disaster recovery systems are of particular significance (Rubinoff \& Courtney, 2008). Hence, integrating both "environmental and societal contributions to resilience without neglecting the differences between environmental and societal characteristics" (Weichselgartner \& Kelman, 2015, p. 263) is essential to place-based adaptation management.

The character and role of social relationships and features of social emergence, which can be analysed using the concept of social capital, also needs to be considered. According to Putnam et al. (1993, p. 167), social capital refers to "features of social organization, such as trust, norms, and networks, that can improve the efficiency of society by facilitating coordinated actions." So-called cognitive elements of social capital describe features such as norms of reciprocity, solidarity, and levels of trust. Structural elements of social capital include formal organisational structures and "networks of civic engagement" (Putnam et al., 1993, p. 174; cf. Krishna \& Shrader, 1999). According to Arrow $(2000$, p. 4), the facilitation of building, maintaining, and strengthening relationships not only improves feelings of social cohesion and community identity but also somewhat incidentally strengthens trust in, and the efficiency of, institutions. How social capital can be relevant for different purposes can be understood by distinguishing different types of social capital. As Petzold (2016) shows, different types of social capital have different implications for access to resources relevant to adaptation. Moreover, the relevance of different types of social capital depends on the institutional setting, geographic conditions, and social and environmental history. So-called bonding social capital refers to family relationships and close friends, networking social capital refers to more distant relationships (e.g., associates and colleagues), and linking social capital involves connections to people and institutions beyond one's community (Woolcock, 2001, p. 13). Each type gives access to different kinds of resources and information, which can be relevant for different kinds of adaptation needs-e.g., financial, physical, informational.

Returning to the concept of ecotones, how do social relationships reflect the influence of both the marine and the terrestrial ecosystem? Moreover, what relevance could that have for community adaptability to environmental change? Gillis (2014, p. 160) suggests that "living with the shore" reflects the environmental features of ecotones by understanding the coast as a dynamic and connecting zone rather than as a border or barrier. For coastal management and climate change adaptation, this implies that people's perception and institutional concepts of the coast have to be considered and potentially 
built upon. The relationship to and use of the coastal environment, for example, affects people's perception of risks (Ratter \& Possekel, 2000). Milfont et al. (2014, p. 6) find that "proximity to the coast was associated with increased belief that climate change is real." An indicator for a community's perception of environment is "social memory" (Wilson, 2015), which in coastal zones can refer to the marine environment as well. Social memory involves shared experiences of environmental events which happened in the past but also involves coping mechanisms. Social memory is formed and preserved by language, literature, and stories, as well as by social capital through keeping up traditions and practices referring to the coastal environment, e.g., in clubs and social networks. Similarly, local knowledge is essential to increasing community resilience through providing skills and behavioural patterns adapted to specific local environmental conditions (cf. Mercer et al., 2012). Local knowledge is valuable in combination with social capital because it can help mobilise existing social capital into action for a specific purpose. Local knowledge, here, refers not only to traditional knowledge but also to knowledge and skills brought in by newcomers. Local knowledge is dynamic. While traditional knowledge refers to land management practices or disaster recovery mechanisms, 'new' local knowledge offers the potential to integrate new skills and ideas to the management of environmental changes, e.g., through linking social capital.

\section{Methods}

For the comparative study of two small coastal areas impacted by similar stressors and with similar social structures, a quantitative approach was both appropriate and feasible. During a field work phase in February/March 2014, a household survey was distributed to all households in the two communities. In Flushing, a drop-and-collect method was applied; in the Isles of Scilly, surveys were distributed in the same manner, but collected with collection boxes in central points of the respective islands. The survey 'Community and the Sea' included 27 questions on social capital, perception of risk, and attitude towards adaptation. Data for the quantitative survey in the Isles of Scilly was based on the research presented by Petzold (2017). The results from the Isles of Scilly were compared with those from Flushing and discussed from the perspective of ecotones.

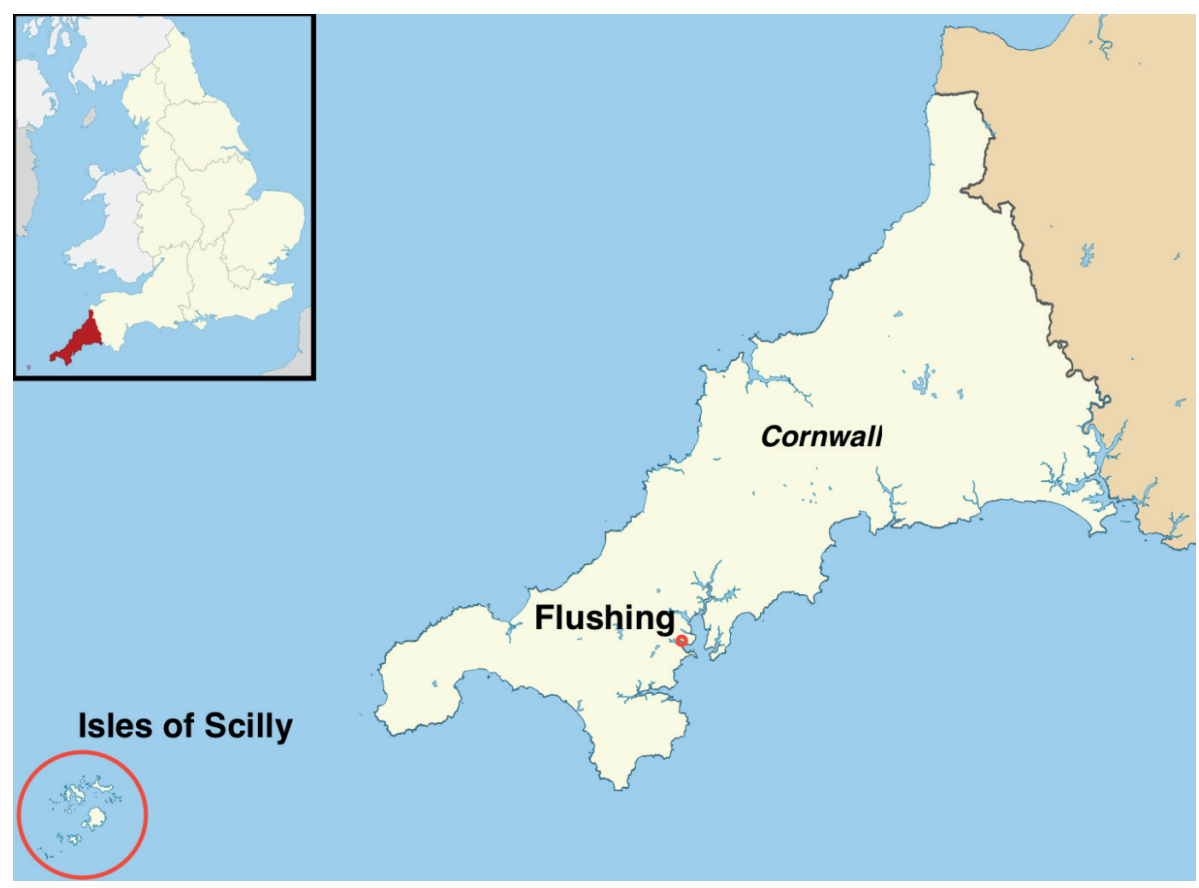

Figure 1: Map of Cornwall, with case study sites: the Isles of Scilly and Flushing. (Contains OS data (C) Crown copyright and database right, 2017) 
Moreover, the quantitative approach is complemented by participant observation and stakeholder interviews. In Flushing, this involved a semi-structured interview with a representative from the local council, non-structured interviews with local inhabitants, and several observations of erosion and post-flooding conditions of the town. For an extended analysis of the qualitative research approach in the Isles of Scilly, see Petzold (2016).

\section{Community-based adaptation in Flushing and the Isles of Scilly}

The two case studies, two 'small' places in Southwest England (see Figure 1), were chosen for their vulnerability to sea-level rise as well as their features of scale and isolation. The relevance of the ecotone and social capital for adaptation, however, differs. In the following, I analyse the placespecific features in the selected case studies regarding social conditions, social capital, and adaptation.

Case study sites

The first case study is Flushing, a village of 670 inhabitants, located on the southern coast of Cornwall, one of the most peripheral counties in England. While Flushing itself is a small village that is not particularly well-connected with major transport links, it lies in proximity to the capital of Cornwall, Truro, and close to another centre of the region, Falmouth, which is located across the estuary of the Penryn River, on which Flushing is also located. The local marine and coastal ecosystem is shaped by the Fal Estuary with a tidal range of up to 5.7 metres. The estuary is designated as a Special Area of Conservation (SAC) and part of the Cornwall Area of Outstanding National Beauty (AONB). The warm seawater temperatures of the estuary's southwesterly location and the relatively low freshwater input provide habitats for a high diversity of marine species in flora and fauna, such as mearl and seagrass beds with bass, cuttlefish, and oyster populations, classified as Priority Habitats under the Natural Environment and Rural Communities Act 2006 (NERC) (Natural England, 2015).

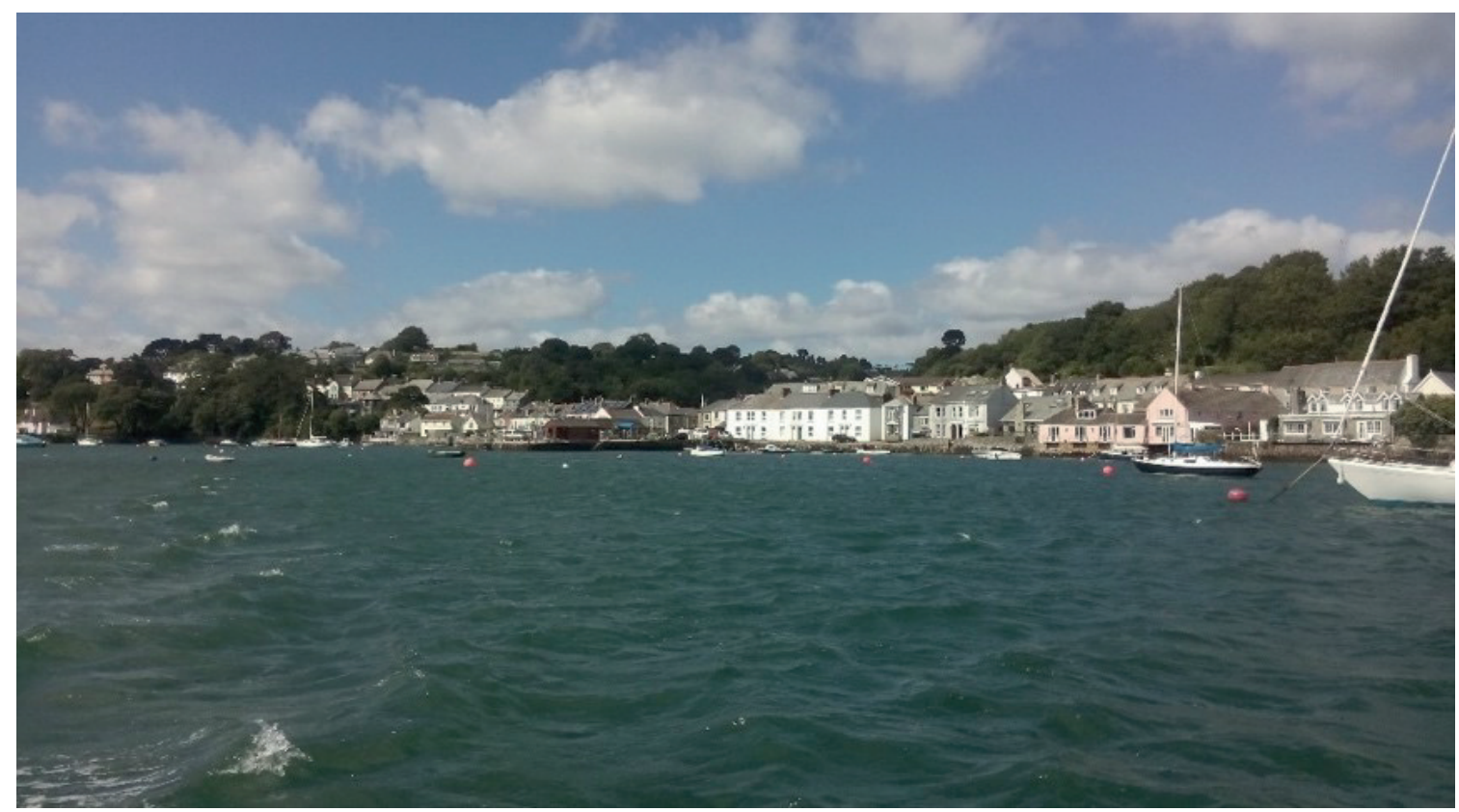

Figure 2: Flushing, July 2014. (C Jan Petzold)

Flushing town was founded in the 17th century. The port (as a sub-port to Falmouth) was constructed by Dutch engineers who migrated from the Netherlands. Historically, the economy was based on shipbuilding, fishing (e.g., oysters), farming, and temporarily copper mining. However, 
Flushing was originally a settlement for people working in the famous harbour of Falmouth. In particular, Flushing was used as a residential area for high-ranking captains from some of the ships docked at Falmouth (University of Portsmouth, n.d.). Today, the main source of income is tourism or employment in one of the main centres mentioned above. Part of Flushing is built at sea level and part is built up a slope (see Figure 2). Every spring tide causes flooding of the village centre, and the main road can hardly be used. Otherwise, storm events usually have limited impact on Flushing, due to its sheltered position with respect to the main wind directions.

The second case study, the Isles of Scilly, is an archipelago composed of five inhabited islandsone larger main island and four smaller so-called 'off-islands'-approximately $45 \mathrm{~km}$ off the southwest tip of Cornwall. All the islands are composed of granite rock and are shaped by the North Atlantic current, which results in relatively mild temperatures, as well as strong and frequent winter storms. The archipelago features a frequently changing coastline with raised beaches and drowned landscapes, which, at low tide (tidal range of up to 5.9 metres), reveal prehistoric field systems. In fact, until around $2000 \mathrm{BC}$, most of the islands were still connected as one big island (Mortimer et al., 2013). The legend of the mythical lost land of Lyonesse is said by some to refer to a submerged land connecting Cornwall and the Isles of Scilly (Mitchell, 2016). The coastal ecosystem of the Isles of Scilly is characterised by "distinctive flora and fauna with some species confined totally to the archipelago, [...] nationally important coastal and heathland habitats, [...] seabird populations" as well as "seagrass beds of international importance" (Isles of Scilly AONB, 2010, p. 42).

Historically, the Isles of Scilly have gone through different phases with shifting economic sectors dominating - including shipbuilding, fishing, subsistence agriculture, and flower farming. Today, as in Flushing, the key economic sector is tourism, while flower farming also remains an important business, for which the islands are famous. While, agriculture is no longer as relevant economically or as a subsistence resource as it once was, it still takes an important role in land stewardship. Legally, the Isles of Scilly are not part of Cornwall since they are a Unitary Authority. However, historically and culturally, they are closely connected to the mainland region. The five islands are inhabited by around 2,200 people (Office for National Statistics, 2011), with approximately two-thirds living on the main island, St Mary's, and concentrated there in Hugh Town. The key infrastructure and administration are also located in Hugh Town. The town is the lowest settlement, its centre being constructed on a sand bar (see Figure 3), and parts of Hugh Town are even below sea level. Storm events and flooding often affect the islands, but erosion is also a significant issue around the islands.

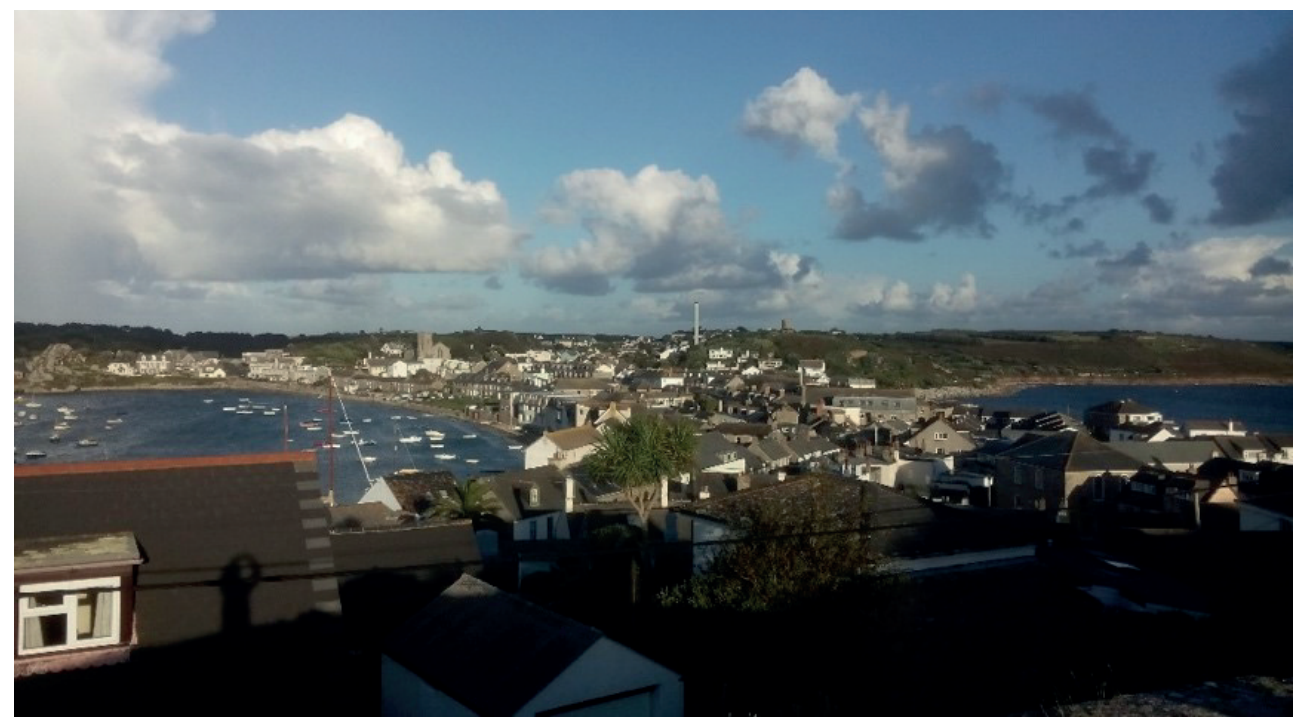

Figure 3: Hugh Town, September 2015. (C Jan Petzold) 


\begin{tabular}{|l|l|l|}
\hline & Flushing & Isles of Scilly \\
\hline Survey response rate & $26 \%(\mathrm{n}=74)$ & $21 \%(\mathrm{n}=191)$ \\
\hline Mean age & 63 years & 62 years \\
\hline Born locally & $7 \%$ & $20 \%$ \\
\hline Time living in $\mathbf{x}$ & 21 years & 32 years \\
\hline
\end{tabular}

Table 1: Survey, key figures.

Before analysing the challenges for the communities for adaptation to sea-level rise, the following section will describe some indicators of social capital in the respective case studies.

Social capital

Regarding the two case studies, social capital-i.e., levels of cooperation, trust, and social networksis especially interesting if it shows particular patterns regarding the geographic and marine environment. Thus, pertinent questions here include how far collective action is explicitly or implicitly related to the coastal and marine environment, how far social relationships shape or are a product of a specific local maritime identity, and how far social networks cross the coastal 'border'.

The household survey received a relatively high response rate in both locations and reflects the high average age and a high ratio of incomers, although the latter factor applies slightly less to the Isles of Scilly (see Table 1).

It can generally be said that social capital is high in the two communities. Several indicators reflect a high degree of bonding social capital, i.e., high levels of trust and helpfulness (see Figure 4 and Figure 5). High levels of trust can be observed, for example-in the Isles of Scilly and partly also in Flushing-where people do not lock their front doors.

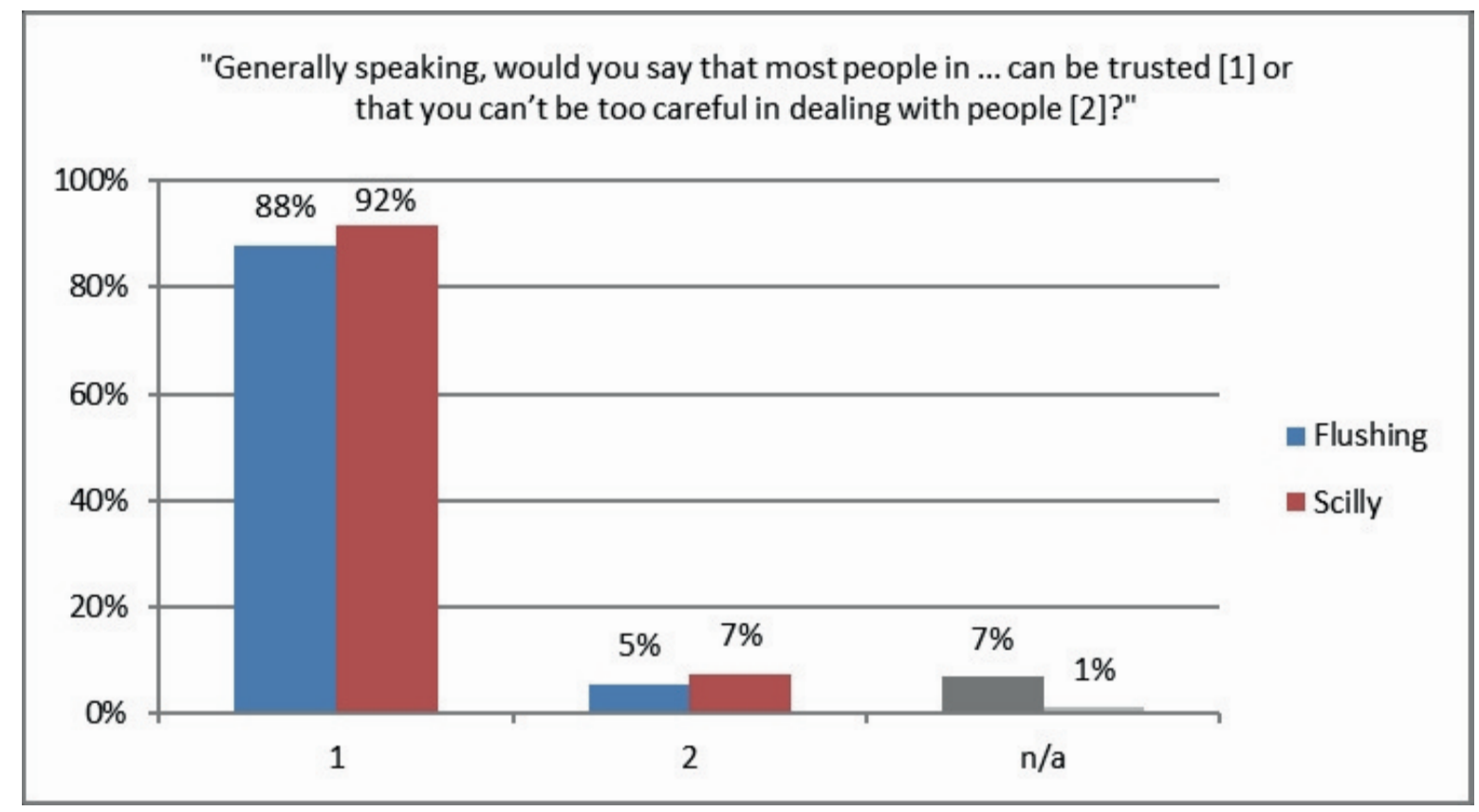

Figure 4: Perceived levels of trust in Flushing and the Isles of Scilly. 


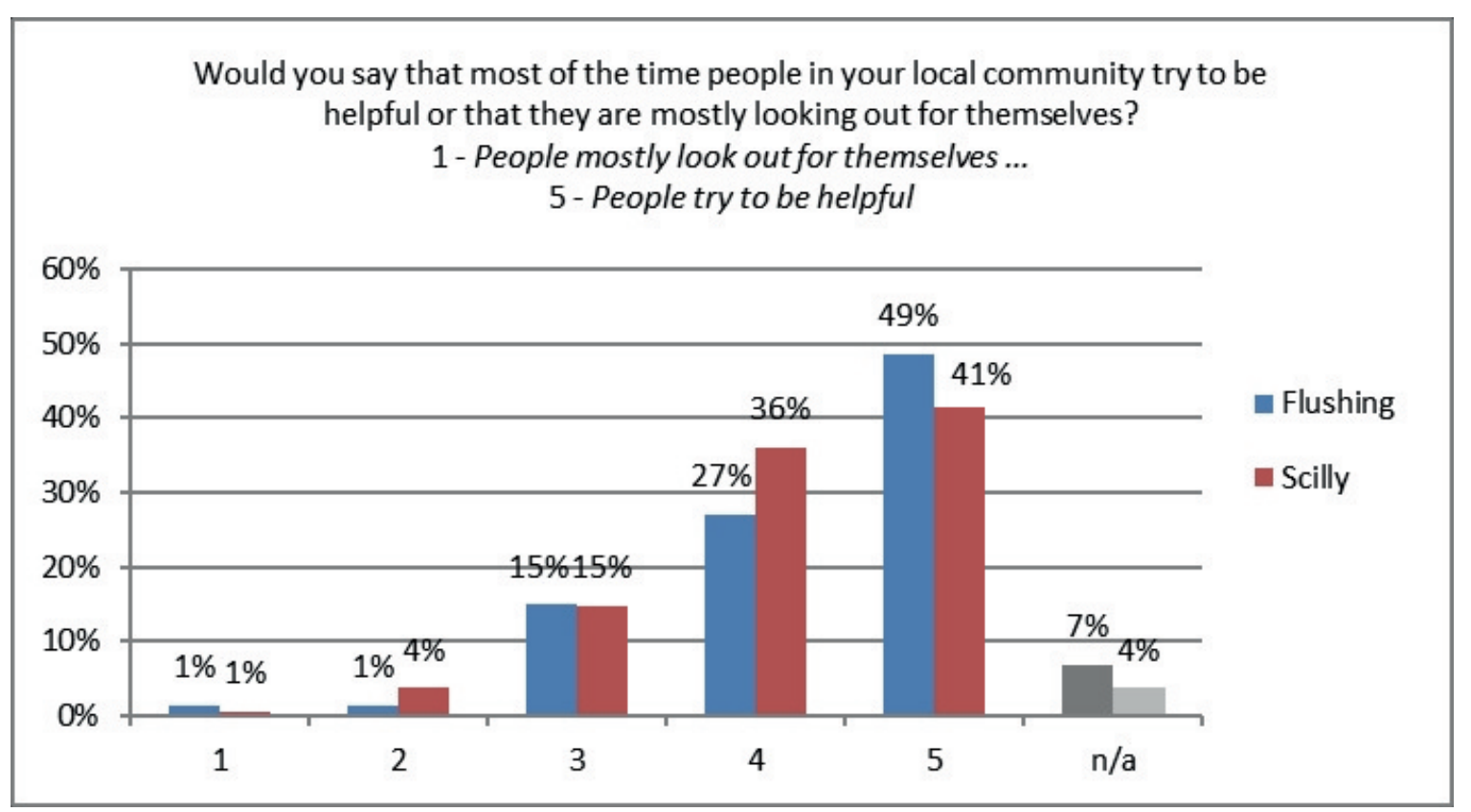

Figure 5: Perceived helpfulness in Flushing and the Isles of Scilly.

A more formal indicator for (networking) social capital is participation in clubs. The most popular clubs in both case studies involve gig rowing-a traditional water sport in Cornwall. Especially in the Isles of Scilly, membership of one of the many gig rowing clubs is high and plays an important role for community spirit, not only within one island, but through the many competitions across the whole archipelago.

Sports clubs, social clubs, and social spaces, such as pubs, provide arenas for bonding and networking social capital. People share information, knowledge, and possibly resources. High degrees of social capital allow for a higher capacity of collective action in a community, while, at the same time, joint activities strengthen social bonds and trust. In contrast to the Isles of Scilly, Flushing has further opportunities for clubs and events in nearby places, such as Falmouth or Truro. Schools and higher education institutions can also be reached more easily from Flushing than from the islands. Therefore, there is a higher degree of access to resources through linking social capital-more distant relationships with people outside one's community.

An issue affecting the social structure of both places is their high ratio of second-home owners. As mentioned above, tourism plays an important role in the communities' economies. Aside from seasonal tourism, day tourism or short-term tourism, for the last few decades more and more homes within the communities have been sold to people living in other parts of the country-possibly former tourists. These homeowners spend only part of the year, often the summer months, in the community and sometimes also rent out their homes to tourists. This results in a seasonal fluctuation of inhabitants and a certain degree of segregation. Often the places sold are the ones close to the shore-the most attractive and valued properties for the tourism sector (especially in Flushing). Also, many of the people who have bought property in Flushing or the Isles of Scilly are retired people, which explains the relatively high average age. These factors of a high average age, and changes in the economic focus from agriculture and fishing to tourism, have consequences for a community. When there is a lack of families and young and productive people, land management skills are lost and certain services cannot be offered any more, such as schools or a voluntary fire brigade (which is a particular problem on the small off-islands of the Isles of Scilly). 


\section{Sea-level rise and adaptation}

Due to their low-lying geography, both Flushing and the Isles of Scilly are threatened by sea-level rise. In fact, sea-level records show an increasing trend in the region (see Figure 6 and Figure 7). Implications of further sea-level rise include increased impacts of tidal surges and associated flooding (see Figure 8), as well as coastal erosion. Especially in the Isles of Scilly, erosion is a concern for all five islands of the archipelago. Besides the main settlement, Hugh Town, which is located on an isthmus, relatively little high-value property is located at the coast, and so the main issue in the Isles of Scilly is the impact of storm surges and flooding. Ultimately, sea-level rise may make Hugh Town uninhabitable. In Flushing, sea-level rise would intensify the problem of flooding during high tides and cause problems for the infrastructure and housing in the town centre as well.

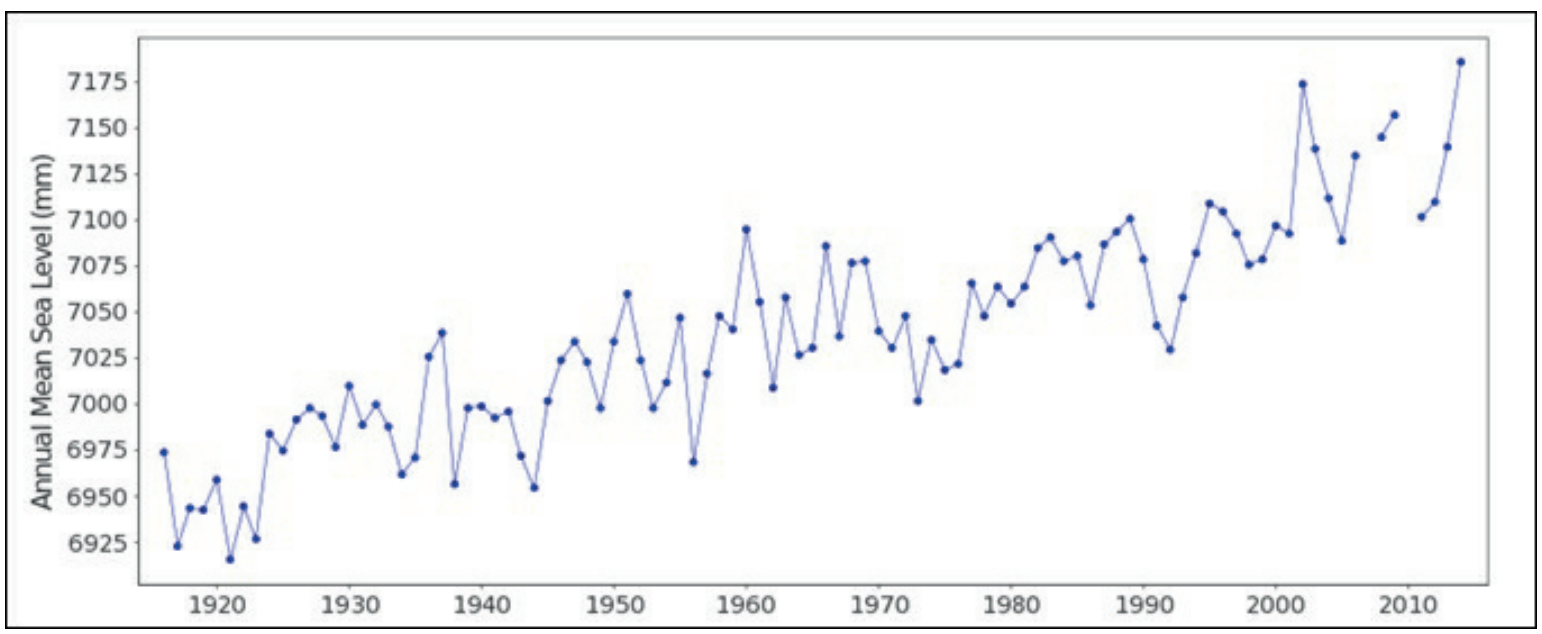

Figure 6: Annual mean sea levels since about 1920 in Newlyn, Cornwall. (Source: psmsl.org)

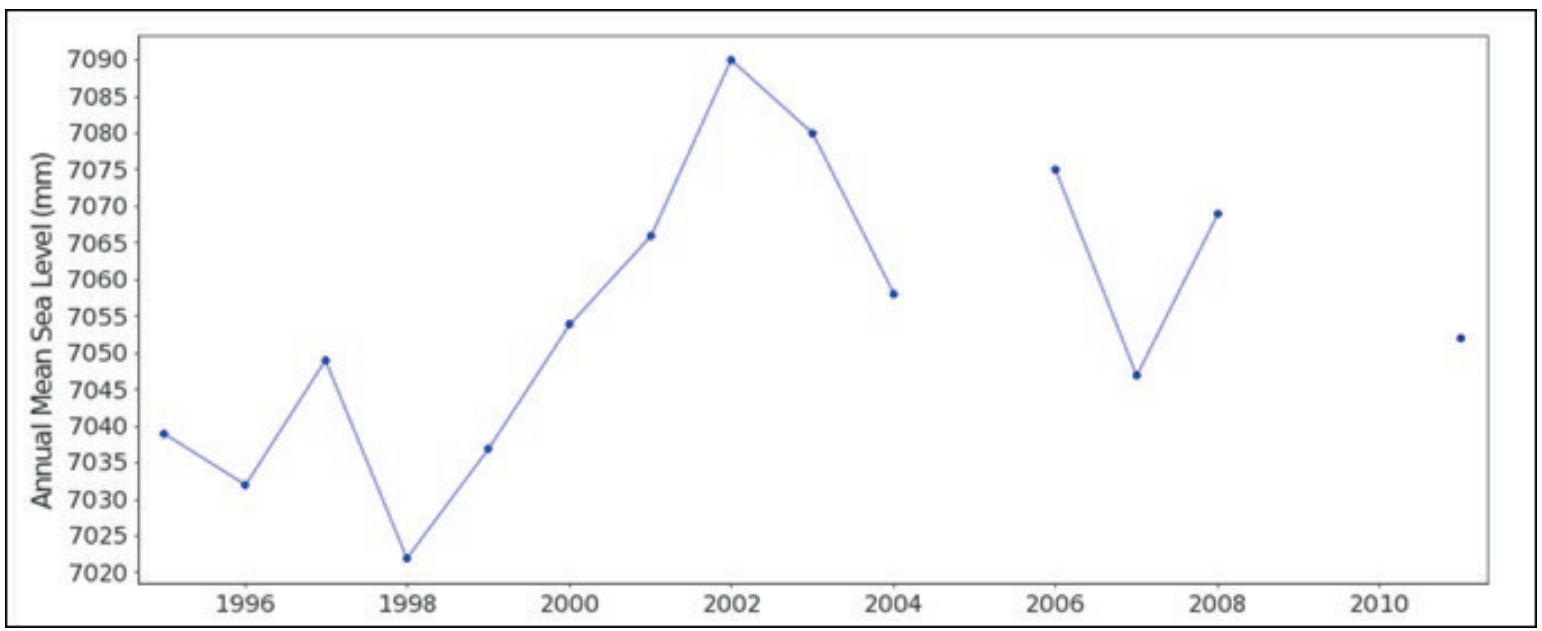

Figure 7: Annual mean sea levels since 1995 in St Mary's, Isles of Scilly. (Source: psmsl.org) 

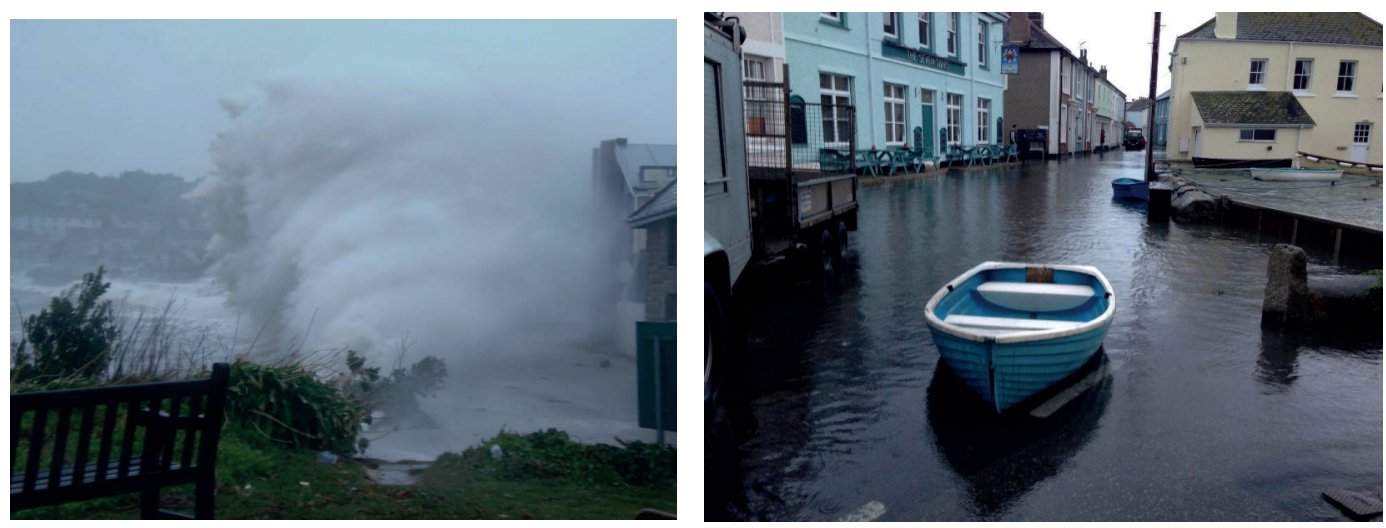

Figure 8: Storm surge hitting Hugh Town (left, (C) A. Martin, 2014); flooding in the town centre of Flushing (right, (C) S. Coles, 2014).

Although climate change projections lack precision for small localities such as the two case studies, both communities nevertheless have a high awareness of the risks associated with sea-level rise and coastal flooding (Figure 9); more than a third of both populations (Flushing: $36 \%$, Isles of Scilly: 39\%) would consider relocating. This is unsurprising in light of the strong storm events the Isles of Scilly are faced with every winter (and especially in the winter 2013/2014). Flushing is used to regular flooding of the town centre at peak tides.

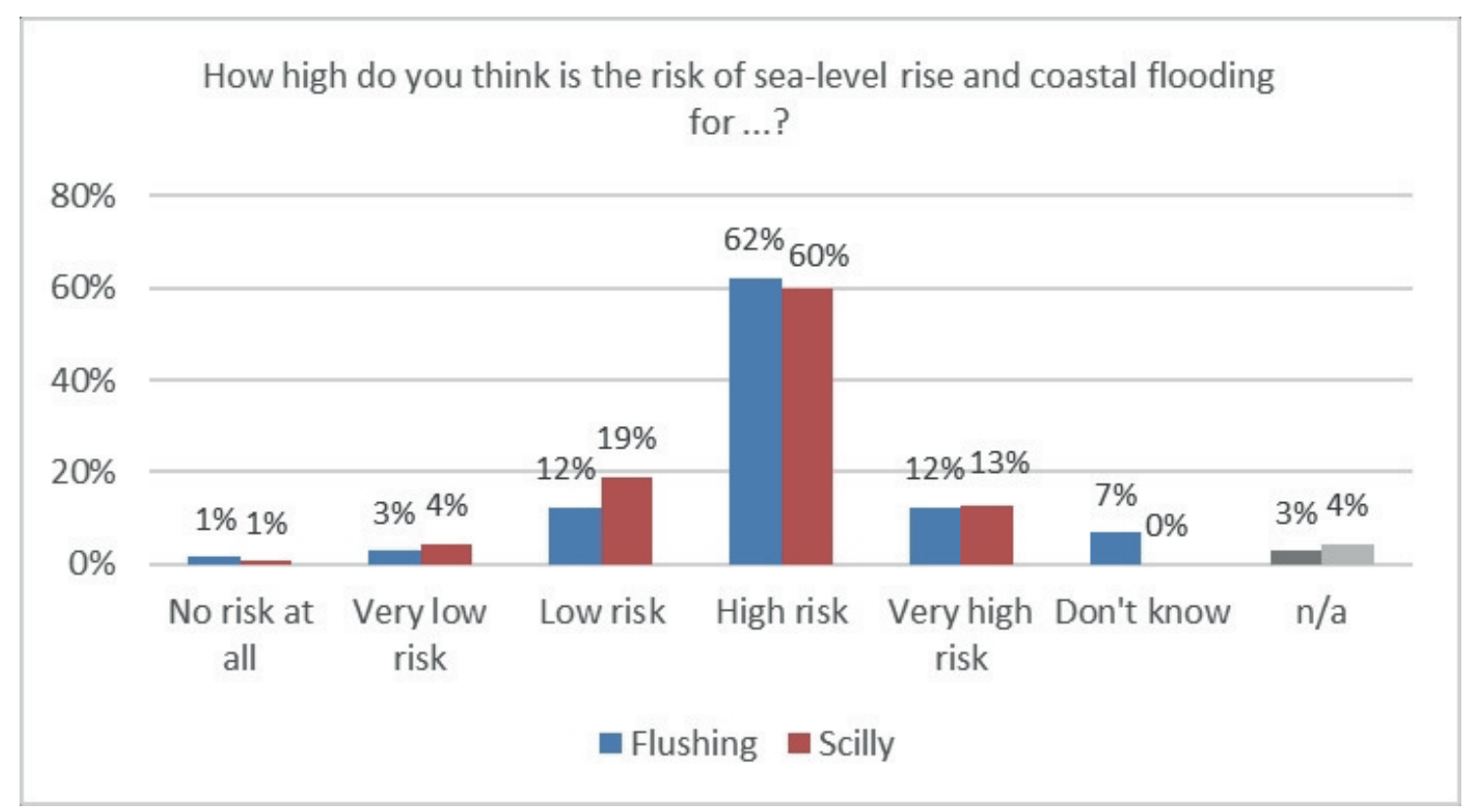

Figure 9: Awareness of risk of sea-level rise and coastal flooding in Flushing and the Isles of Scilly.

While the quantitative survey data cannot answer the question of whether the long-term inhabitants on the islands or in Flushing are more aware of risks or less alarmed (both surveys were undertaken in winter, when few second-home owners or tourists are present), the qualitative approach of semi-structured and non-structured interviews with locals supports the hypothesis that native islanders as well as people who have lived in Flushing for a long time are less alarmed by extreme weather conditions and uncertain projections of future developments. This, however, does not imply that they are less proactive.

Coastal protection is an important issue in both communities. In Flushing, a major floodgate protects the main road and properties from flooding. However, during spring tides the installed valves push the sea water back to the road, and this protection does not always work as 
intended. Protection against flooding is, therefore, mainly an individual responsibility. Most homes in the flood-prone area of the village use sandbags or have flexible flood boards, which are put out in advance of flood events, or left in place most of the time in the case of holiday homes, which are left uninhabited for long periods.

In the Isles of Scilly, different kinds of coastal protection are necessary. Hugh Town is protected by sea walls. Some of the off-islands have dykes (Figure 10). Apart from that, the islands are relatively exposed to the forces of waves and storm events. In extreme cases, sandbags are distributed by the council, and people fill them individually or collectively with sand from a local beach and use them as a complement to flood boards. The Environment Agency is responsible for the hard infrastructure in both cases. In the long run, both communities will have to find other solutions to protect their respective settlements, as higher peak tides and extreme events intensify the problems which are already being experienced, and hard infrastructure, such as seawalls, cannot solve the problem. In the Isles of Scilly coastal erosion threatens not only settlements but also agricultural areas and archaeological monuments.
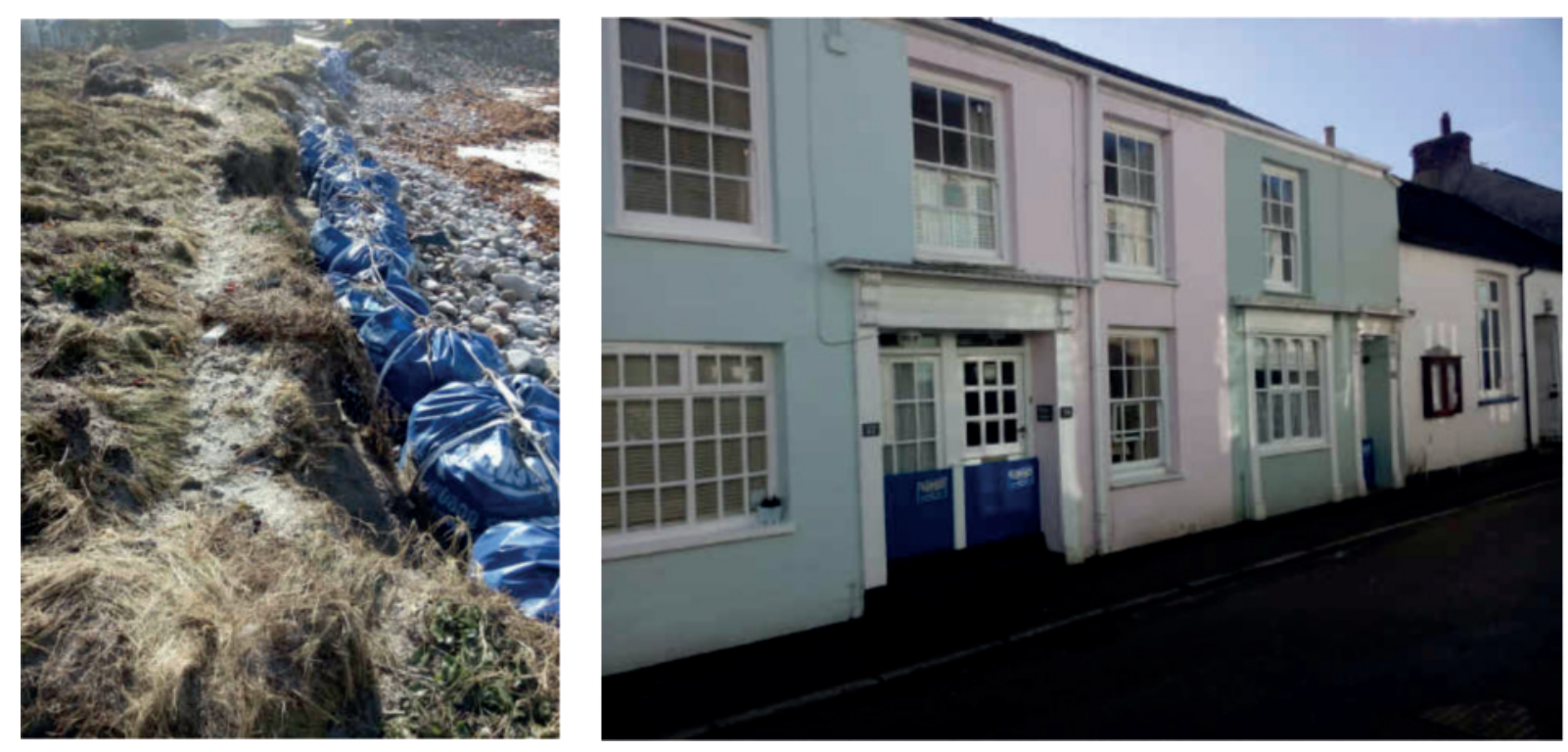

Figure 10: Stabilisation of dyke on St Agnes (left); flood boards in front of holiday flats in Flushing (right).

The household survey shows that in both communities, the majority of respondents believe the local authorities should be more active in protecting their communities from the effects of sea-level rise and coastal flooding. In the Isles of Scilly, this majority (76\%) is even higher than in Flushing (62\%). Almost a third of the respondents in Flushing do not want the local authorities to be more active. This is a rather high number, given the regular flood events and the low-lying village centre. Accordingly, in Flushing, fewer people (58\%) would support extra spending by the local council for flood and coastal protection than in the Isles of Scilly (85\%).

Another question in the household survey addressed people's expectations in relation to national government. In both communities, two-thirds of the respondents expect more support, while almost one-third do not; figures which show that quite a high proportion of residents have accepted the rather isolated setting of their respective community, where funds directly from the national government or associated agencies are rarely allocated to the local administrations for infrastructure or coastal protection schemes. 


\section{Community-based adaptation}

The question then is, what is the role of the community regarding adaptation to the described pressures, which will probably increase with further sea-level rise? Asked about participation in coastal protection, in Flushing, the majority (73\%) answered that they were not participating. In the Isles of Scilly, however, almost half (46\%) of the respondents stated that they were taking part in coastal protection efforts. Generally, this involves activities such as beach cleaning and placing sandbags. The results are even more revealing when looking at the different islands of the Isles of Scilly (see Figure 11). Participation is particularly high on the off-islands, and here, maintaining and repairing sea defences was also referred to. On the main island, St Mary's, and on the off-island Tresco-which is managed by a private tourism resort-participation is relatively low. Nevertheless, the lowest participation is in Flushing. In view of the fact that Hugh Town on St Mary's is the most vulnerable place, these results suggest that it is not necessarily the exposure to coastal hazards which makes the difference in perception, but rather smallness, degree of isolation, and necessity for self-help.

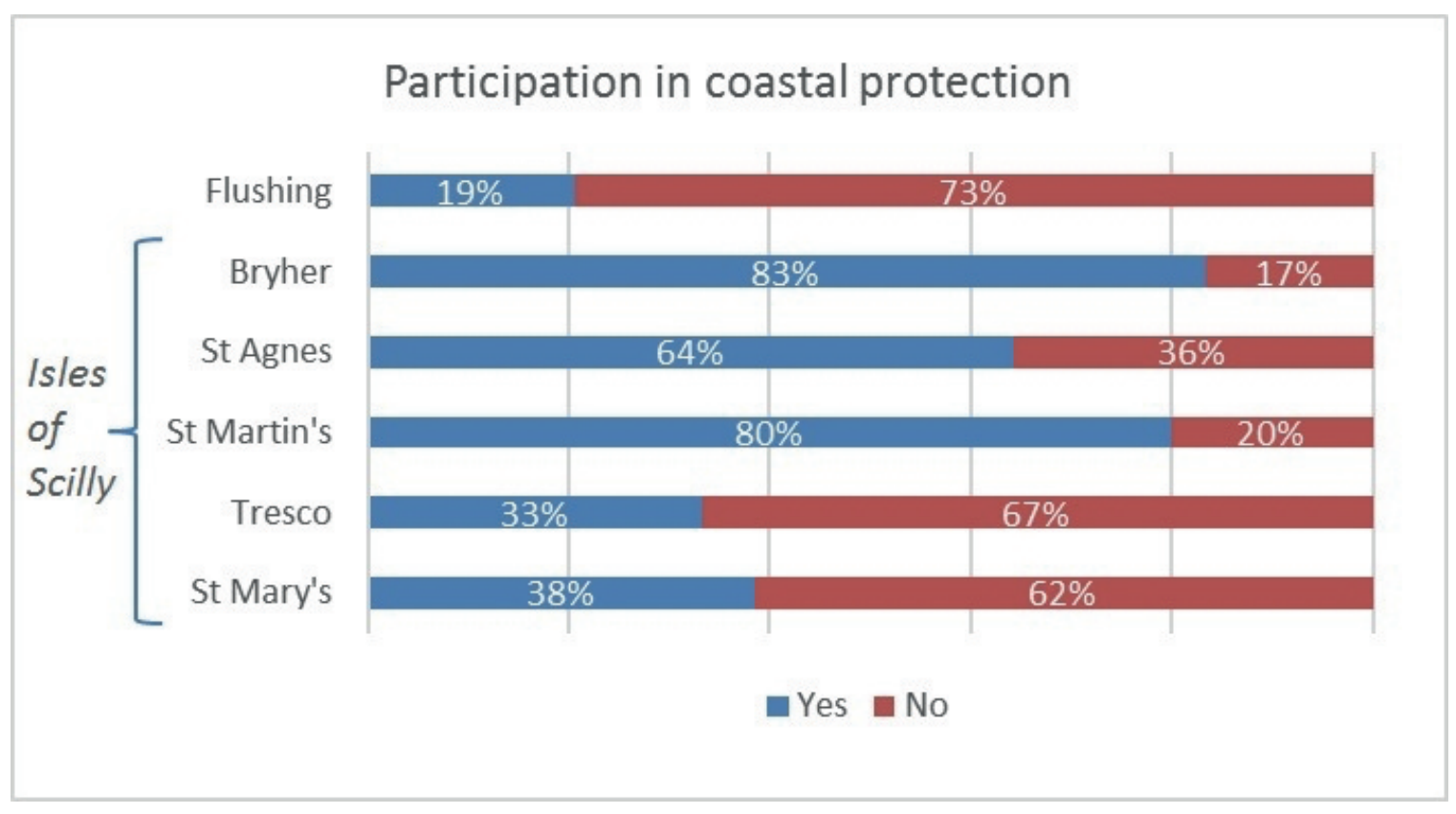

Figure 11: Participation in coastal protection in Flushing and the Isles of Scilly.

It seems as if, on the one hand, Flushing accepts its peripheral role and individual responsibility, while on the other hand, this also leads to a sort of passivity from a communitarian perspective. In the Isles of Scilly, people are aware of their isolation, but still, they have more need of external assistance due to higher exposure to extreme weather events. At the same time, especially on the off-islands, the higher degree of isolation produces an increased necessity for self-reliance and cooperation within the community. Here, the indicators described as social capital-trust, social networks, collective action-become relevant. However, the relevance of social capital differs in Flushing and in the Isles of Scilly. In both communities, helpfulness and trust are important elements. In cases of flooding, people assist each other in placing sandbags and exchange information about upcoming events. Since there is a high degree of fluctuation in the presence of people in the communities, helping neighbours who are not present is important-taking care of their homes on their behalf in times of flooding, for example. Also, collective action, which requires leadership or the availability of physical resources, can be highly relevant in relatively isolated places such as the two case studies. Especially in the Isles of Scilly, where sea defences have to be monitored and maintained, collective action is crucial in times of emergency. There can be a considerable delay before support services arrive on the islands. 
In addition to resources, such as machines and tools, skills and local knowledge are important factors, which promote social capital's role in strengthening community resilience. This includes, for example, the understanding of local tidal rhythms and how to react to spring tides. In Flushing, locals are always informed about the tidal calendar and are, therefore, prepared for high water. They remove their cars and put out flood boards and sandbags. Similarly, in the Isles of Scilly, many people are prepared to manage for several days without the availability of fresh food in times of rough weather. Also, traditional land management skills, such as hedge cutting (Figure 12) and the stabilisation of dunes, contribute to erosion control in the less built-up areas of the islands.

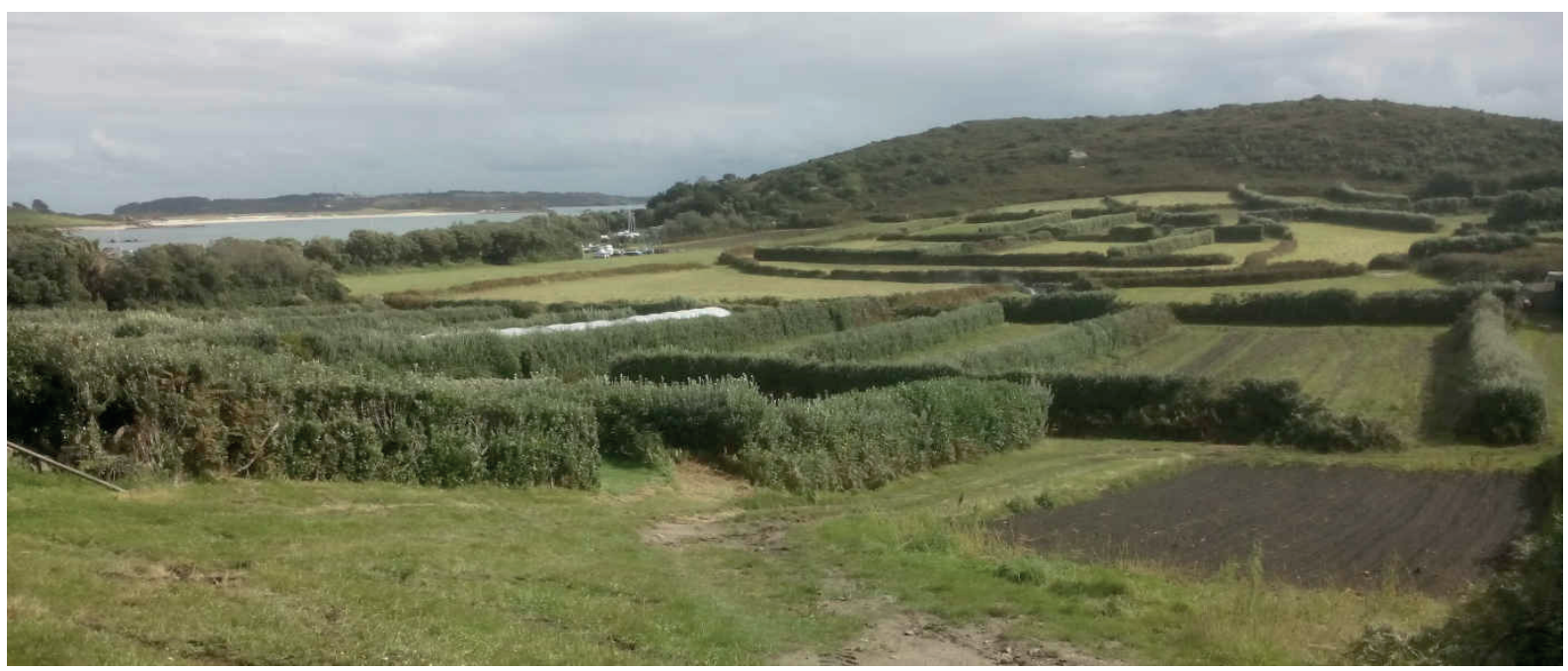

Figure 12: Agricultural fields protected by hedges on Bryher, Isles of Scilly. (C Jan Petzold)

In relation to the historical dimension, both communities have undergone radical changes in their socio-economic structures in the past century, which have moved towards the tourism industry. This change implied a loss of ecotonal life. Technical skills are increasingly lost, with the dominance of the tourism sector and the decrease of the relevance of farming in the Isles of Scilly. However, the boating services between the islands, and similarly between Flushing and Falmouth continue to run as a service not only for locals but also for tourists. The boatmen are among the most informed people concerning weather conditions and changes to the marine environment. While the tourism sector still links communities to their respective terrestrial and marine environment, local life has lost its ecotonal character. The tourism industry relies on the natural environment; however, an understanding of its dynamics and the interactions between the marine and the terrestrial are not necessarily the foundation for its functioning.

\section{Discussion}

The comparison of the results from the two case studies regarding social adaptability to climate change can be discussed in a wider context, picking up the concept of ecotones, coastal zones in times of global change, a perspective of complexity theory, and the study of islands.

Is it possible to identify the specific character of life in coastal communities that could be termed 'ecotonal' (cf. Gillis, 2014)? Maritime identity is an important factor that is related to social capital and is unique to coastal areas (probably most strongly associated with small islands but also with small coastal regions in general). Both communities show features of 'maritime people' (Rainbird, 2007) —as also described in Hayward's aquapelago concept—by their high identification with their coastal environment and important social activities such as sporting (gig rowing), which are still popular. While in Flushing the marine environment has not always been 
the most important contemporary factor for livelihoods, it is probably the most important factor for place attachment. In the Isles of Scilly, the ratio of 'native' islanders and the time people have lived in the community is relatively higher, which might contribute to the understanding of and interaction with the local environment. Resilience also means knowing how to live under certain circumstances, e.g., with permanent risk of flooding or isolation due to extreme weather conditions. Activities such as gig rowing or boating services are not only important for social capital, but also contribute to people's shared knowledge of the coastal and marine environment. The experience and knowledge of the local coastal dynamics enable people to adapt to environmental changes individually and collectively, particularly by increasing self-reliance in more remote and isolated places, such as the Isles of Scilly.

How can ecotones be understood in times of global change? Where are ecotones? It seems harder to identify ecotones from a social sciences point of view. In fact, coasts are no longer places effectively 'used' by people, at least regarding their terrestrial as well as their marine resources (Steinberg, 2001). Similarly, instead of living with the dynamics of the coastal ecological systems, coastal protection is understood as 'controlling nature' (Gillis, 2012). Many coasts-not only, but particularly, in the so-called Global North-are shaped by built-up land, and people rely on livelihoods other than those directly relating to their local coastal environment, as is shown in the two case studies. While Flushing relies on the local environment only indirectly-through its attractiveness for tourists-the Isles of Scilly still engage in agriculture, fishing, and flower farming, in addition to their focus on tourism, which, again, is based on the 'beauty' of the place, referring to the combined terrestrial and marine system. In contrast to the past, where communities and individuals were responsible for land stewardship, today institutionalised natural protection schemes and frameworks are in place. Thus, social change and economic developments have transformed formerly place-based coastal communities (in this case, especially the Isles of Scilly) and led to a decrease in reliance on natural resources or knowledge of the natural coastal environment; but the latter is still the foundation of the development and everyday life of the two case study communities.

The natural environment and its complexity and dynamics are still shaping people's feeling of a common identity and social memory, which results in a high awareness of risks and, to a certain degree, also a high coping capacity. In a social-ecological system, the social system needs to be understood as open, dynamic, and non-linear (Sawyer, 2005). As mentioned above, the demographic change of the two case studies also affected their interaction with the coastal environment. The growing tourism development and second-home ownership resulted in a loss of traditional local knowledge and land management practices. However, it also introduced new resources and ideas through linking social capital, which might be important for a community's resilience in a changing world, where no place is completely independent. For example, financial resources brought in by incomers to the coastal communities can become relevant for investments into climate change mitigation projects. An increase in linking social capital can be crucial in case it comes to forced relocation due to the impacts of sea-level rise, e.g., in low-lying deltas and Small Island Developing States (SIDS).

Since islands are often used as showcases for vulnerability to global (climate) change (Barnett \& Waters, 2016; Kelman \& West, 2009), this paper could also contribute to the question of whether there is any significant difference between the results of the island and mainland case studies. Both of the case studies feature issues of scale (smallness) and issues of isolation (geographic periphery), which affect their adaptability (cf. Kerr, 2005). The Isles of Scilly seem, on the one hand, more isolated geographically and, on the other, more self-reliant. The small local council has little capacity for large-scale adaptation measures, which is why in this respect the community relies on external funding and organisations. However, in times of emergency and for small-scale informal action, the island community seems much more adaptable than Flushing. In Flushing, exposure to extreme events is also lower, and the community is relatively better connected to centres and potential assistance in times of emergency. Certainly, in the Isles 
of Scilly, the strong feeling of a common identity as islanders not only refers to native islanders but also to new inhabitants. Thus, there might be a higher potential to maintain or revive traditional ways of living with the sea on such islands.

It is important to bear in mind that "islands and mainlands are not easily separated; in fact, they are interdependent parts of a larger world that includes coasts and hinterlands as well as all that lies between" (Gillis, 2007, p. 277). However, the specific island spatiality-or 'islandness'-makes it easier to conceptualise islands as ecotones that also shape society, while continental coastal places are always embedded in a wider hinterland with the ecotone effect as rather marginal. Moreover, islands are social constructions and easier to conceptualise as well as to perceive as places (cf. Gillis, 2007). The unique sense of place they represent-not only for islanders but also for visitors and mainlanders-might even promote more involvement with the local coastal environment and its changes. In addition, the perceived boundedness of island spatiality makes them seemingly more manageable (Grydehøj \& Kelman, 2017, p. 109).

\section{Conclusion}

What can a social science perspective add to the concept of ecotones, and vice versa? Sustainable management of coasts and islands can be promoted by understanding their social-ecological dynamics. Such an understanding refers, on the one hand, to the geomorphological dynamics of the intertidal and coastal zone, and on the other hand to changing anthropogenic perceptions, use of, and interference with the coast, as well as the potential of community action in vulnerable areas. This and many other studies (e.g., Baldacchino, 2005; Groome Wynne, 2007; Kilpatrick \& Falk, 2003; Petzold, 2016; Petzold \& Ratter, 2015) showed that social capital can be an important resource for various purposes on small islands, including adaptation to climate change.

The relevance of social capital for collective action regarding coastal protection and direct adaptation to sea-level rise, however, largely depends on local cultural, geographical, and historical contexts. Many coastal places, which in the past were shaped by their ecotonal character, today seem to be increasingly shaped by the influences of anthropogenic terrestrialbased developments (Gillis, 2012). The case studies show that despite much local knowledge being lost, day-to-day life in a tidal environment shapes people's place sensitivity and potentially their resilience towards sea-level rise. Therefore, research and adaptation planning should not merely focus on features of traditional local knowledge and traditions of collective action but also analyse everyday practices and mental constructions, values, and perceptions of coasts in 'modern' societies.

The study of ecotones, moreover, can be a step to advance the discussion regarding an alleged dichotomy between islands and continents (cf. Stratford et al., 2011). However, research on ecotones from a social sciences perspective requires stronger empirical foundations. Island studies' goal of understanding islands "on their own terms" (McCall, 1994), as well as related approaches focusing on the archipelago (Baldacchino, 2006; Pugh, 2013; Stratford et al., 2011), the aquapelago (Hayward, 2012), and island-sea-ship relationships (Pugh, 2016) allows it to provide a valuable foundation for analysing people-place relationships in a dynamic coastal environment, without generalising features of vulnerability (Barnett \& Waters, 2016; Kelman, 2010; Moore, 2010). While islandness and island spatiality are specific issues to be studied, taking the dichotomy between islands and mainlands as a given bears epistemological risks. Thus, the social construction of islands and the role of hinterlands need to be considered when discussing ecotones, in particular in comparison to continental case studies, to avoid mistaking "our continental projections for island realities" (Gillis, 2007, p. 286).

Climate change is an example of environmental change implying a great deal of uncertainty. Therefore, a perspective on resilience that accounts for local social and environmental dynamics and coping capacities is necessary (cf. Ratter, 2013). The concepts of ecotones and the aquapelago help to point out that marine ecosystems play a fundamental role, 
not necessarily only in relation to livelihoods, but also in relation to feelings of identity and belonging, which influence people's attitudes and actions in terms of environmental pressures and coastal protection. Understood as a historical approach, Gillis's ecotone perspective offers the opportunity to include the specific contradictions and developments of coasts in modernity; how coastal places are perceived, constructed, and deconstructed (cf. Ratter et al., 2016; Steinberg, 2001). Directed towards the future, the approach of seeing islands and coastal zones as ecotones can thus contribute to finding sustainable adaptation options and avoiding top-down adaptation strategies, which potentially lead to disadvantages for the local communities.

\section{References}

Adger, W.N. (2003). Social capital, collective action, and adaptation to climate change. Economic Geography, 79(4), 387-404. https://doi.org/10.1111/j.1944-8287.2003.tb00220.x

Arrow, K.J. (2000). Observations on social capital. In P. Dasgupta \& I. Serageldin (Eds.) Observations on social capital (pp. 3-5). Washington, DC: World Bank.

Baldacchino, G. (2006). Islands, island studies, Island Studies Journal. Island Studies Journal, 1(1), 3-18. Baldacchino, G. (2005). The contribution of 'social capital' to economic growth: lessons from island jurisdictions. The Round Table, 94(378), 31-46. https://doi.org/10.1080/00358530500033075

Barnett, J. \& Waters, E. (2016). Rethinking the vulnerability of small island states: climate change and development in the Pacific Islands. In J. Grugel \& D. Hammett (Eds.) Rethinking the Vulnerability of Small Island States: Climate Change and Development in the Pacific Islands (pp. 731-748). London: Palgrave Macmillan. https://doi.org/10.1057/9781-137-42724-3 40

Berkes, F. \& Ross, H. (2013). community resilience: toward an integrated approach. Society $\mathcal{E}$ Natural Resources, 26(1), 5-20. https://doi.org/10.1080/08941920.2012.736605

Gillis, J.R. (2014). Not continents in miniature: islands as ecotones. Island Studies Journal, 9(1), 155-166.

Gillis, J.R. (2012). The Human Shore: Seacoasts in History. Chicago: University of Chicago Press. https://doi.org/10.7208/chicago/9780226922256.001.0001

Gillis, J.R. (2007). Island sojourns. Geographical Review, 97(2), 274-287. https://doi.org/10.1111/j.1931-0846.2007.tb00403.x

Groome Wynne, B. (2007). Social capital and social economy in sub-national island jurisdictions. Island Studies Journal, 2(1), 115-132.

Grydehøj, A. \& Kelman, I. (2017). The eco-island trap: climate change mitigation and conspicuous sustainability. Area, 49(1), 106-113. https://doi.org/10.1111/area.12300

Harrison, S. \& Stainforth, D. (2009). Predicting climate change: lessons from reductionism, emergence, and the past. Eos, Transactions American Geophysical Union, 90(13), 111-112. https://doi.org/10.1029/2009EO130004

Hau'ofa, E. (1993). Our sea of islands. In E. Waddell, V. Naidu, and E. Hau'ofa (Eds.) A New Oceania: Rediscovering Our Sea of Islands (pp. 2-16). Suva: University of the South Pacific.

Hayward, P. (2012). Aquapelagos and aquapelagic assemblages. Shima, 6(1), 1-11.

IPCC (2013). Summary for policymakers. In T.F. Stocker, D. Qin, G.-K. Plattner, M. Tignor, S.K. Allen, J. Boschung, A. Nauels, A., Y. Xia, V. Bex, \& P.M. Midgle (Eds.) Climate Change 2013: The Physical Science Basis. Contribution of Working Group I to the Fifth Assessment Report of the Intergovernmental Panel on Climate Change (pp. 3-29). Cambridge, UK \& New York: Cambridge University Press.

Isles of Scilly AONB (2010). The Isles of Scilly AONB management plan 2010-2014. Retrieved from $\quad$ http://www.ios-aonb.info/wp-content/uploads/2012/09/IoS-AONBSTRATEGIC-PLAN-2010-2014-LR.pdf

Kelman, I. (2010). Hearing local voices from Small Island Developing States for climate change. Local Environment, 15(7), 605-619. https://doi.org/10.1080/13549839.2010.498812 
Kelman, I. \& West, J.J. (2009). climate change and small island developing states: a critical review. Ecological and Environmental Anthropology, 5(1), 1-16.

Kerr, S.A. (2005). What is small island sustainable development about? Ocean \& Coastal Management, 48(7-8), 503-524. https://doi.org/10.1016/j.ocecoaman.2005.03.010

Kilpatrick, S. \& Falk, I. (2003). Learning in agriculture: building social capital in island communities. Local Environment, 8(5), 501-512. https://doi.org/10.1080/1354983032000143662

Krishna, A. \& Shrader, E. (1999). Social capital assessment tool. Prepared for the Conference on Social Capital and Poverty Reduction. The World Bank. Washington. Retrieved from http://siteresources.worldbank.org/INTSOCIALCAPITAL/Resources/Social-CapitalAssessment-Tool--SOCAT-/sciwp22.pdf

Lyth, A., Harwood, A., Hobday, A.J., \& McDonald, J. (2015). Place influences in framing and understanding climate change adaptation challenges. Local Environment, 21(6), 730-751. https://doi.org/10.1080/13549839.2015.1015974

Magis, K. (2010). Community resilience: an indicator of social sustainability. Society \& Natural Resources, 23(5), 401-416. https://doi.org/10.1080/08941920903305674

McCall, G. (1994). Nissology: a proposal for consideration. Journal of the Pacific Society, 17(2-3), $1-14$.

Mercer, J., Kelman, I., Alfthan, B., \& Kurvits, T. (2012). Ecosystem-based adaptation to climate change in caribbean small island developing states: integrating local and external knowledge. Sustainability, 4(12), 1908-1932. https://doi.org/10.3390/su4081908

Milfont, T.L., Evans, L., Sibley, C.G., Ries, J., \& Cunningham, A. (2014). Proximity to coast is linked to climate change belief. PLoS ONE, 9(7), e103180. https://doi.org/10.1371/journal.pone.0103180

Mitchell, M. (2016). The lost lands of Lyonesse: telling stories of Cornwall and the Isles of Scilly. Shima, 10(2), 94-111.

Moore, A. (2010). Climate changing small islands: considering social science and the production of island vulnerability and opportunity. Environment and Society: Advances in Research, 1(1), 116-131. https://doi.org/10.3167/ares.2010.010106

Mortimer, T.A.L., Scourse, J.D., Ward, S.L., \& Uehara, K. (2013). Simulated late-glacial and Holocene relative sea-level and palaeotidal changes on the Isles of Scilly: a new approach for assessing changes in the areal extent of the inter-tidal zone. Geoscience in South-West England, 13, 152-158.

Natural England (2015). Fal and Helford Special Area of Conservation: Site Information (draft). Retrieved from https://www.gov.uk/government/publications/marine-conservationadvice-for-special-area-of-conservation-fal-and-helford-uk0013112/fal-and-helford-sacsite-information-draft

Nurse, L., McLean, R.F., Agard, J., Briguglio, L., Duvat, V., Pelesikoti, N., Tompkins, E.L., \& Webb, A. (2014). Small islands. In V.R. Barros, C.B. Field, D.J. Dokken, M.D. Mastrandrea, K.J. Mach, T.E. Bilir, M. Chatterjee, K.L. Ebi, Y.O. Estrada, R.C. Genova, B. Girma, E.S. Kissel, A.N. Levy, S. MacCracken, P.R. Mastrandrea, \& L.L. White (Eds.) Climate Change 2014: Impacts, Adaptation, and Vulnerability. Part B: Regional Aspects. Contribution of Working Group II to the Fifth Assessment Report of the Intergovernmental Panel on Climate Change (pp. 1-60). Cambridge, UK \& New York: Cambridge University Press.

Office for National Statistics (2011). 2011 Census: usual resident population, local authorities in the United Kingdom. Table KS101UK. Retrieved from http://www.ons.gov.uk/ons/rel/census/2011-census/population-and-householdestimates-for-the-united-kingdom/rft-table-2-census-2011.xls

Pelling, M. (2011). Climate Change and Social Capital. Foresight Project. London: Government Office for $\quad$ Science. $\quad$ Retrieved from http://www.bis.gov.uk/assets/foresight/docs/international-dimensions/11-1029-climatechange-and-social-capital.pdf 
Petzold, J. (2017). Social Capital, Resilience and Adaptation on Small Islands: Climate Change on the Isles of Scilly. Cham: Springer. https://doi.org/10.1007/978-3-319-52225-8

Petzold, J. (2016). Limitations and opportunities of social capital for adaptation to climate change: a case study on the Isles of Scilly. The Geographical Journal, 182(2), 123-134. https://doi.org/10.1111/geoj.12154

Petzold, J. \& Ratter, B.M.W. (2015). Climate change adaptation under a social capital approach - an analytical framework for small islands. Ocean \& Coastal Management, 112, 36-43. https://doi.org/10.1016/j.ocecoaman.2015.05.003

Pugh, J. (2016). The relational turn in island geographies: Bringing together island, sea and ship relations and the case of the Landship. Social \& Cultural Geography, 17(8), 1-20. https://doi.org/10.1080/14649365.2016.1147064

Pugh, J. (2013). Island movements: thinking with the archipelago. Island Studies Journal, 8(1), 9-24.

Putnam, R.D., Leonardi, R., \& Nanetti, R. (1993). Making Democracy Work: Civic Traditions in Modern Italy. Princeton, NJ: Princeton University Press.

Rainbird, P. (2007). The Archaeology of Islands. Cambridge, New York: Cambridge University Press. https://doi.org/10.1017/CBO9780511619007

Ratter, B.M.W. (2013). Surprise and uncertainty: framing regional geohazards in the theory of complexity. Humanities, 2(1), 1-19. https://doi.org/10.3390/h2010001

Ratter, B.M.W., Petzold, J., \& Sinane, K. (2016). Considering the locals: coastal construction and destruction in times of climate change on Anjouan, Comoros. Natural Resources Forum, 40(3), 112-126. https://doi.org/10.1111/1477-8947.12102

Ratter, B.M.W. \& Possekel, A.K. (2000). 'Island Systems Management' als Planungsstrategie für das Ressourcen- und Hazardmanagement kleiner Inseln. In H.H. Blotevogel, J. Oßenbrügge, \& G. Wood (Eds.) Lokal verankert - weltweit vernetzt. Tagungsbericht und wissenschaftliche Abhandlungen (pp. 187-193). Stuttgart: Steiner.

Rubinoff, P.B. \& Courtney, C.A. (2008). How resilient is your coastal community? a guide for evaluating coastal community resilience to tsunamis and other hazards. Basins and Coasts, 2(1), 24-28.

Sawyer, R.K. (2005). Social Emergence: Societies as Complex Systems. Cambridge: Cambridge University Press. https://doi.org/10.1017/CBO9780511734892

Steinberg, P.E. (2001). The social construction of the ocean. Cambridge, UK: Cambridge University Press.

Stratford, E., Baldacchino, G., McMahon, E., Farbotko, C., \& Harwood, A. (2011). Envisioning the archipelago. Island Studies Journal, 6(2), 113-130.

University of Portsmouth (n.d.). History of Flushing, in Carrick and Cornwall: Map and description. A Vision of Britain through Time. Retrieved from http://www.visionofbritain.org.uk/place/21417

Walker, B.H. \& Salt, D. (2006). Resilience Thinking: Sustaining Ecosystems and People in a Changing World. Washington, DC: Island Press.

Weichselgartner, J. \& Kelman, I. (2015). Geographies of resilience: challenges and opportunities of a descriptive concept. Progress in Human Geography, 39(3), 249-267. https://doi.org/10.1177/0309132513518834

Wilson, G.A. (2015). Community resilience and social memory. Environmental Values, 24(2), 227-257. https://doi.org/10.3197/096327114X13947900182157

Woolcock, M. (2001). The place of social capital in understanding social and economic outcomes. Isuma: Canadian Journal of Policy Research, 2(1), 11-17. 